\title{
Service quality of building services consultants in building project delivery; clients' perspectives
}

Opeyemi Oyeyipo , Bamidele Adeyemi , Innocent Osuizugbo \& Rapheal Ojelabi

To cite this article: Opeyemi Oyeyipo , Bamidele Adeyemi , Innocent Osuizugbo \& Rapheal Ojelabi (2020): Service quality of building services consultants in building project delivery; clients' perspectives, International Journal of Construction Management, DOI: 10.1080/15623599.2020.1829784

To link to this article: https://doi.org/10.1080/15623599.2020.1829784

册 Published online: 14 Oct 2020.

Submit your article to this journal

Џ Article views: 55

Q View related articles ¿

View Crossmark data ¿ 


\title{
Service quality of building services consultants in building project delivery; clients' perspectives
}

\author{
Opeyemi Oyeyipo ${ }^{a}$, Bamidele Adeyemi ${ }^{b}$, Innocent Osuizugbo ${ }^{c}$ and Rapheal Ojelabi ${ }^{d}$ \\ ${ }^{a}$ Department of Quantity Surveying, Bells University of Technology, Ota, Nigeria; ${ }^{b}$ Estate Links Limited, Lagos, Nigeria; ${ }^{\mathrm{c} D e p a r t m e n t}$ of Building, \\ Bells University of Technology, Ota, Nigeria; ${ }^{d}$ Department of Building, Covenant University, Ota, Nigeria
}

\begin{abstract}
The role of consultant services engineers in the construction process is pivotal as they make significant contributions towards successful delivery of construction projects. They are responsible for ensuring that the technical specifications and design standards of mechanical, electrical and plumbing aspects of construction projects are adhered to with due consideration to budget and schedule. The quality of services offered by these consultants have however become a source of worry to clients recently in Nigeria as reflected in variance in the quality of services they render. This study examined clients' assessment of service quality of consultant services engineers in building project delivery. The study adopted survey research design with a total 121 responses obtained from target respondents using structured questionnaire administered to clients' organizations. The study adapted the 22 SERVQUAL service quality variables from literature. The study discovered that client's expectation of service quality of building services consultant exceeded the actual perceived service in building project delivery. Clients are unimpressed with the ability of the consultants to show sincere interest, provision of services at the time promised, the ability to give client specialized services relating to MEP and willingness to help client. Out of date software is being used and clients are rarely satisfied with consultants' responsiveness and assurance. It is imperative for service consultants to understand client's expectations and ensure such needs are met in the construction delivery process in order to ensure the service quality gap is eliminated. Finally, there is the need for consultants to be conscientious by timeously responding to all instructions and requests of clients as well as improve reputation which will ultimately pay off in project outcome.
\end{abstract}

\section{KEYWORDS}

Building project; building services consultant; client; perception; satisfaction; service quality

\section{Introduction}

The activities of the construction industry involve the complex interactions of relevant stakeholders. Oyeyipo et al. (2019) opined that there is a string of interrelationship between stakeholders which results in the achievement of client's objectives. Different individuals as well as organizations are involved in the delivery process with different and varying interests, which affect or are affected by the products of the industry. However, the complexity of the construction sector has not affected its input to the development of the economy. Tayeh et al. (2018) buttressed that the construction industry provides the national economy with the much-needed support. Majority of literature reckons schedule delay, loss and expense claim are among other major factors that cause conflict and construction disputes (Ojelabi et al. 2018). Construction consultants are important for achievement of the client's objectives in the delivery of construction projects. Construction consultants are part of the primary team members (PTMs) in any construction project with significant involvement and responsibilities throughout all phases of the project. Lichtig (2006) posited that PTMs including construction consultants make sound contributions and decisions to the project delivery process. This important group are the client, contractors, architects, quantity surveyors, structural engineers and services engineers, amongst others in construction project delivery.
The consultant services engineer is one of client's representatives during the process of project construction. Services engineers are associated with the mechanical and electrical aspect of construction project and are the professionals that make significant contributions and guarantee the effective running and efficient delivery of construction projects. One of the major responsibilities of service engineers is to ensure that the technical specifications and design standards of mechanical, electrical and plumbing (MEP) works of construction projects are adhered to without affecting the set budget and schedule. Dadzie et al. (2012) maintained that a number of the main obligations of the consultant service engineers are design review, evaluation of operations of contractors, re-assessment of MEP contractor's work, quality control tests, appraisal of valuation of work done for services, review of claims and the requests for extension of time as well as the preparation of periodic progress reports for the section of works. The quality of services offered by these consultants has become a source of concern in recent times (Rosli and Hamsa 2005). The problem of poor service quality is however evident with the dearth of building services consultants in the Nigerian construction industry. This is reflected in variance in the quality of services MEP consultants provide in construction project delivery in the country.

According to Eshghi et al. (2008), service quality is the complete evaluation or assessment of the service rendered to a client or customer by the client or customer. Ghylin et al. (2008) 
corroborated that delivering higher quality of services by any organization will result into increased customer satisfaction. Measuring service quality of important construction consultants such as MEP consultants is essential for successful project delivery in the construction sector. Limited literatures have assessed the service quality of building service engineers in building project delivery. For instance, Dosumu and Aigbavboa (2019) examined client's perception of service quality of construction consultants in delivery of construction projects. In the same vein, while Tan (2012) examined the architect's perception of the consulting engineer's service quality in building project delivery, Chow and $\mathrm{Ng}$ (2003) carried out performance-based evaluations for engineering consultants in construction project delivery. Therefore, it could be inferred that studies regarding service quality of building services consultants (BSC) in building project delivery is sparse. Hence, the study aims to examine client's assessment of service quality of BSC in building project delivery with the view to improving clients' satisfaction in building project delivery. To achieve the aim, the study sets out to pursue the following research questions: (a) what are the perceptions and expectations of clients on the service quality of building services consultants in building project delivery? (b) what is the gap in service quality of building services consultants in building project delivery?

Outcome of this research provided a detailed understanding of the need to bridge the lacuna between the expectation and perception of clients concerning service delivery of building services consultants in project delivery. The study provides insights into the level of satisfaction of client about consultants mechanical and electrical engineers in building project delivery and the efforts required in closing the gap between expected and observed performance from the client during project execution.

\section{Literature review}

\section{Building service engineering consultants in building project delivery}

Generally, consultant engineers are specialists who have been well trained and are professionally engaged in any field of engineering. Amongst others, these fields include civil, mechanical, electrical, electronic and petroleum. These professionals function in a diverse range of construction projects, from consulting firms to research corporations. For example, some of the functions of engineers include but not limited to research and development, teaching, designing, manufacturing and construction, testing and consulting (Kemper 1990).

In the construction industry, building services engineers are also referred to as mechanical and electrical (M\&E) engineers. Tan (2012) explained that services engineers are also responsible for the design of air conditioning, heating ventilation and plumbing systems. Fire protection engineers are however mostly engaged independently. Electrical engineers are those in charge for the distribution of power, fire alarm, lighting systems, telecommunication and lightning protection within the building envelope.

In building projects, it is important to place great emphasis on previous performance(s) when selecting or appointing services engineering consultants for building projects (Chow and $\mathrm{Ng}$ 2003). This is because quality service is one of the major indicators to ascertain the competency of BSC in finishing a building project satisfactorily. According to Ullman (2001) and Christodoulou et al. (2004), the breakdown or failures of some construction projects are attributed to design error, deficient technical solution as well as poorly administered contract offered by services consultants. In this regard, Hattan and Lalani (1997) stressed that the intricacies of construction projects in terms of technical and contractual basis, calls for the engagement of capable consultant engineers to protect the interests and rights of clients. Gyadu-Asiedu (2009) posited that the construction industry in developing countries, at different levels of socio-economic development have realized the importance of the industry which has necessitated taking strategic measures to enhance project performance. One of the ways to achieve this is for consultants to guarantee efficiency in the execution of construction projects.

\section{Service quality and customer satisfaction: the Nexus}

A customer could also be referred to as a client in the construction sector. Studies have shown that, the terms customer, enduser and client can be used synonymously due to closeness in their definitions (Othman 2015). The concept of customer satisfaction originated in the early 1980s in United States. Customer satisfaction has been an important subject in behavioural studies and has been defined differently across various disciplines. The meaning of customer satisfaction is referred to as being theoretical which differs from one industry to another (Oluwatayo et al. 2014). While Aga and Safakli (2007) defined satisfaction as the response of client as to whether a service or project is yielding desirable level of usefulness, Dosumu and Aigbavboa (2019) measured satisfaction by weighing the difference of expected service/outcome from actual service rendered. Nunkoo et al. (2019) described customer satisfaction as the degree of the disparity between clients' belief about a product or service and their assessment of such product or service after completion. These definitions indicate that clients are satisfied when a desire is fulfilled although satisfying some clients might be difficult. The complicated characteristics of human perception and behaviour have therefore made the concept of customer satisfaction an interesting research area in many industries (Tahanisaz and Shokuhyar 2020).

Client's satisfaction is premised on the performance of the service quality of construction consultants, especially when the expectations of clients are achieved (Dosumu and Aigbavboa 2019). Consulting firms that consistently satisfy their clients are likely to enjoy greater profitability at all times. It is pertinent to note that the necessity for service quality consideration is very essential because organizations and construction consultants depend on it for survival and profitability. The delivery of professional service and reputation of service providers have been found to influence client satisfaction (Oluwatayo et al. 2014). Ingle and Mahesh (2020) noted that the construction project success evaluation has been developed to include non-financial performance aspects like customer relation, employee motivation and stakeholder satisfaction so as to effectively manage construction projects. Thus, there is the need to always ensure that clients are satisfied by establishing and bridging the gap between their expectation and perceptions.

Service can be referred to as an activity rendered by an individual or organization in order to satisfy a client. As noted by Olanrewaju (2016), service users can be dissatisfied or satisfied based on the services received (i.e. whether the service met the assessment of the services or not). Service differs from service quality. The latter has been conceptualized as one of the constructs in service delivery, which measures a critical gap between clients' expectations and observations (Forsythe 2015). Roy et al. 
(2019) described service quality as customer's general opinion about the quality of the service, and that conceptualization of the service quality is in both tangible and easily measurable quality (e.g. defection rate) and intangible aspects (e.g. heterogeneity among service providers). Dosumu and Aigbavboa (2019) noted that improved service quality as delivered by primary project team members plays a significant role in enhancing client's value and achieving construction projects success.

Satisfaction of client is closely related to the construct of service quality amidst the theoretical underpinning in the expectancy-disconfirmation theory (Nunkoo et al. 2019). The service quality assessment of any service is considered a herculean task; therefore, the providers of a service should be proactive in managing those aspects by which a service is assessed (Viadiu et al. 2002). The assessment of service quality is an important indicator of client's satisfaction in several industries (Oluwatayo et al. 2014; Nunkoo et al. 2019; Govender et al. 2019). Dosumu and Aigbavboa (2019) stated that consulting firms should prioritize the provision of top-notch services during the discharge of the duties. Love et al. (2000) outlined three dimensions of service quality including (i) Hygiene factors (the expectations of client and if not discharged will result to client's dissatisfaction); (ii) Pleasing factors (the delivery of such actions which ensures client satisfaction while the non-delivery of such which necessarily does not cause disappointment); and (iii) Dual threshold factors (the delivery of such actions above the requisite standard guarantees client's satisfaction while it's delivery below the standard will certainly cause dissection).

It is reported that the service delivery of consultants in the construction project delivery fall below the expectations of client in the discharge of their services with varying degree in different part of the world. In UK, Cox and Thompson (1997) stated that the inefficiency in construction project services have been associated partly with construction consultants among others. This assertion has resulted into the failure to meet the needs of the clients/users of such projects. However, $\mathrm{Ng}$ (2005) indicated that while the quality of service of construction consultants was within the acceptable range, it was revealed that some projectrelated aspects of the construction deliverable turned in as less satisfactory by clients. The service quality of construction consultants in Nigeria is haphazard and which is complicated with their poor disposition to innovative changes which will improve client's satisfaction (Usman et al. 2012). It is imperative that building services consultants should brace up to close the service quality gap in order to achieve client's objectives and ultimately improve satisfaction of the users and the clients of such construction products.

\section{Service quality measurement}

Service quality is ascertained by measuring the concept against the customer expectations. There is often a propensity to focus on the present and past instead of focussing on the future when measuring service quality (Love et al. 2000). This gives room for service quality enhancement. Different scholars have designed different methods for service quality measurement. For instance, Parasuraman et al. (1988) established a quality gap model known as SERVQUAL for the determination of service quality gap. The model describes service quality as the differences between the client's expectation and actual observation of the actual service delivered (Love et al. 2000; Olanrewaju 2016; Tahanisaz and Shokuhyar 2020). This quality gap is also influenced by other gaps, for example, differences between: (i) Service quality specifications and observed service (ii) Observed service and external communications about the service (iii) project team leader's observations of end user's expectations and service quality specifications and (iv) Project manager's perceptions of client's expectations and end user's actual expectations (Parasuraman et al. 1988). The quality gap model is a concept with multi-dimensional impact that comprises of five dimensions to include tangibility, responsiveness, reliability, assurance and empathy (Forsythe 2015; Roy et al. 2019; Nunkoo et al. 2019). The SERVQUAL programme is an approach designed for the assessment of the service quality of decision making units (Nojavan et al. 2020). Service quality is best measured with SERVQUAL model (Dosumu and Aigbavboa 2019) and is most widely used survey instrument for the measurement of service quality (Love et al. 2000; Tahanisaz and Shokuhyar 2020).

Several researchers have criticized the significance of measuring the service quality perceptions and the validity of the operationalization and dimensions of the SERVQUAL model (Forsythe 2015). According to Forsythe (2015), SERVQUAL model has been long in use particularly for the psychometric advantages it offers over and above other models despite the criticism. Many researchers have replicated SERVQUAL model and some recommended that the model be modified to suit each particular service setting (Hoxley 2000). Sallehan et al. (2012) noted that it has been modified and adapted in several studies to suit construction industry. Based on this, the current research adapts the SERVQUAL method to appraise the performance of building services engineers/consultants in building project delivery.

\section{Research method}

The study is aimed at assessing clients' perception of the service quality of building services consultants in building project delivery in Lagos, Nigeria. The research carried out was an organization-based study to assess the expectation and perception of the service quality of building service consultants in the execution of building projects within the study area. Lagos state was selected because of the presence of client organizations, property developers and corporate organizations with head office/operating office within its metropolis. Survey research design was selected to aptly describe the client's perception of service quality of this set of construction consultants. Secondly, the survey research design was selected because majority of service quality studies adopted this type of research design.

Several studies were reviewed to identify service quality constructs adopted for this study and most notably to establish the research gap(s). The review of literature revealed the constructs used in the questionnaire instrument, while a pilot study was carried out for construct and content validation. The research instrument and objectives of the study were first made available to five top experienced construction professionals working in client organizations, property development companies and corporate organisations which formed the responding organizations. Similarly, the research instrument was made available to academic scholars at the cadre of professor of construction management in University of Lagos; one of the foremost University offering construction management and construction commercial management courses in the country. The highlighted corrections were incorporated into the survey instrument before they were administered to the intended target organizations.

The target population for the study are client and/or client representatives involved in the construction process of building projects within the study area. In the study of Idoro (2009), the 
list of clients of recently completed projects was compiled. A total of two hundred and two clients were used for the study which formed the basis for the sample frame for this study. The inability of the present study to obtain an updated and comprehensive list of clients in the country as at the time of carrying out this study necessitated the use of the list. The study implemented a probability sampling method i.e. random sampling technique. The technique was used because it gave the entire sample frame equal probability of being selected in the study. The sample size which depicts the representative of the population was established using Kish equation (1965) cited in Dosumu and Aigbavboa (2019):

$$
n=n^{\prime} /\left[1+\left(n^{\prime} / N\right)\right]
$$

where $N$ total population, $n$ sample size from known population, $n^{\prime}$ sample size from immeasurable population $S^{2} / e^{2}$; where $S^{2}$ variance of the population elements, and $e$ standard error of sampling population (where $S=0.5$ and $e=0.06$ ). Thus, for a sample frame of 232 clients' organizations: $n=53$.

The sample size of 53 respondents obtained in the equation above stipulates the minimum number expected from the population of 232 clients' organizations. However, in this present study, 145 copies of the survey instruments were administered to the target participants. Out of the copies administered, 121 copies of the instrument were retrieved from clients; representing a response rate of $83 \%$.

For achieving objectives of the study, the study adapted the 22 service quality variables as used by Parasuraman et al. (1988) in similar study. There are five major service quality dimensions: tangibles (TA), reliability (RL), responsiveness (RN), assurance (AS) and empathy (EN). Each has four variables, five variables, four variables, four variables and five variables respectively. The research instrument used was divided into four parts (Sections A-D). For this study, Sections A-C were used to elicit data from the respondents. Section A retrieved demographic information of the respondents and responding client organizations. Sections B and $\mathrm{C}$ of the survey instrument were used to collect information about the expectation and perception of client on service quality of service engineering consultants in building project delivery respectively. As stated above, the assessment comprises the expectation and observation scale. While the expectation scale denotes the client's view of an excellent service before services are rendered, the observation scale describes the perception of the rendered service. Hence, the survey instrument was used to elicit data regarding the expectation and actual perception using a 7-point scale where 1 - 'very strongly disagree' and 7 - 'very strongly agree' (Table 1 ).

Cronbach alpha test was used to test the reliability of the responses of the drivers and inhibitors to ERM implementation of contractors. After the test, the Cronbach value of all variables used for the study was 0.878 which is greater than 0.70 , the minimum value of acceptability as presented by Pallant (2010). All the variables in the research instrument were subjected to an inter-item correlation matrix and the values was positive. This confirms that variables in the survey instruments have the same underlying characteristics. The mean inter-item correlation of 0.685 for the study is within the allowable range of $0.48-0.76$ as highlighted by Chen and Mathies (2016). This correlation matrix value confirms that there is a strong association among the variables used in the study research instrument.

The study adopted frequency distribution, mean score and SERVQUAL to analyze the collected data in a bid to provide answers to the highlighted research questions. The following steps are used for calculating the SERVQUAL Score:

Step 1: The score for 22 adapted expectation and perception items for the study is obtained. Thereafter, the difference between expectation and observed score is calculated to obtain the gap score.

Step 2: The gap score for each item in a major dimension is added together and then divided by the number of responses in the dimension; resulting to the average gap score for the dimension. This is done for each of the five service quality dimensions.

Step 3: The average gap score comprising all dimensions (measure of service quality) is obtained by adding the individual dimension gap score and dividing by 5 .

\section{Results and discussions}

This section presents the discussion on the analysis of the collected data for the study. The section provided the basis for inference, conclusion and the practical implications. The section provides information on three sub-heading; information on respondent, expectation and observation of service quality of building services consultants and service quality gap.

Table 2 revealed the frequency distribution of respondents; information that participated in the survey. Quantity surveyors constitute the highest proportion (27\%) of the professionals within the client organizations that participated in the survey. Civil engineers accounted for $20 \%$ of the total population; while other professionals like project managers, builders, estate surveyors/valuers in the built industry were $4 \%$ of the total respondents. Table 2 revealed that about $97 \%$ of the total population received formal education, which positions them to provide reliable information about the assessment of service quality of building service engineer within the built environment. Sixty-three per cent of the total population are known to have work experience of 11 years and above, which infers that the sample selected for the study are suitably informed to assess service quality of building service consultants in the construction process.

\section{Clients' expectation and perception of service quality of building services engineering consultants}

Presented in this section is the first objective of the study which is to examine the expectation and perception of clients on the service quality of building service engineers in the building project delivery. To achieve this objective, 22 variables associated with measuring service quality identified from literature were selected and used in the research instrument. The twenty two variables were classified into five dimensions namely; tangible (TA), reliability (RL), responsiveness (RN), assurance (AS) and empathy (EM). Five variables were classified under tangible and empathy, while four variables were classified each under responsiveness, reliability and assurance. Expectation and perception of the client on the service quality of building service consultants in building project delivery was measured on a 7-point Likert scale. The least number indicate low expectation or low perception while the higher number indicates high expectation or high perception in terms of service quality of building service consultants.

The items with high expectation scores were BSC should have up-to date software $(\mathrm{TA} 1=5.97)$ in the discharge of their duties, the ability of BSC to carry out their tasks as promised $(\mathrm{RL} 1=6.22)$, BSC should show genuine interest in solving issues and concerns during the construction process ( $R L 1=6.22)$, BSC should make information easily accessible by clients and other 
Table 1. Modified variables used in the study.

\begin{tabular}{|c|c|c|c|}
\hline \multicolumn{2}{|r|}{ Parasuraman et al. (1988) } & \multicolumn{2}{|c|}{ Modified items in this study } \\
\hline Dimensions & Items & Expectations & Perceptions \\
\hline \multirow{4}{*}{$\begin{array}{l}\text { Tangibles } \\
\text { (TA) }\end{array}$} & TA1: Up-to-date equipment & BSC will have up-to-date design software & BSC have up-to-date design software \\
\hline & TA2: Physical facilities virtually appealing & $\begin{array}{l}\text { Physical facilities of BSC will be } \\
\text { virtually appealing }\end{array}$ & $\begin{array}{l}\text { Physical facilities of BSC are } \\
\text { virtually appealing }\end{array}$ \\
\hline & $\begin{array}{l}\text { TA3: Employees dressed well and } \\
\text { appear neat }\end{array}$ & BSC will dress well and appear neat & BSC are well dressed and appear neat \\
\hline & TA4: Physical environment is clean & $\begin{array}{l}\text { Physical/work environment of BSC that will } \\
\text { aid his service during the construction } \\
\text { process will be top-notch }\end{array}$ & $\begin{array}{l}\text { Physical environment of BSC that aid his } \\
\text { service during the construction process is } \\
\text { top-notch }\end{array}$ \\
\hline \multirow[t]{5}{*}{$\begin{array}{l}\text { Reliability } \\
\text { (RL) }\end{array}$} & RL1: Doing what is promised on time & $\begin{array}{l}\text { When BSC promise to carry out an action or } \\
\text { activity during the construction process } \\
\text { by a certain time, they do it }\end{array}$ & $\begin{array}{l}\text { BSC do carry out an action or activity as } \\
\text { promised during the construction process. }\end{array}$ \\
\hline & $\begin{array}{l}\text { RL2: Showing sincere interest in solving } \\
\text { customers' problem }\end{array}$ & $\begin{array}{l}\text { BSC will show genuine interest in solving } \\
\text { the design related problems over other } \\
\text { personal interest }\end{array}$ & $\begin{array}{l}\text { When clients have problems, BSC show } \\
\text { genuine interest in solving the design } \\
\text { and project related issues over other } \\
\text { personal interest }\end{array}$ \\
\hline & $\begin{array}{l}\text { RL3: Performance of service right at } \\
\text { first time }\end{array}$ & $\begin{array}{l}\text { BSC perform their project related tasks right } \\
\text { the first time during the } \\
\text { construction process }\end{array}$ & $\begin{array}{l}\text { BSC perform their project related tasks right } \\
\text { the first time during the } \\
\text { construction process }\end{array}$ \\
\hline & $\begin{array}{l}\text { RL4: Provision of services at the } \\
\text { time promised }\end{array}$ & $\begin{array}{l}\text { BSC will provide their services at the time } \\
\text { they promise to do so }\end{array}$ & $\begin{array}{l}\text { BSC provide their services at the time they } \\
\text { promise to do so }\end{array}$ \\
\hline & RL5: Keeping records accurately & $\begin{array}{l}\text { BSC will have a detailed and accurate } \\
\text { document and record } \\
\text { management system }\end{array}$ & BSC keep their records accurately \\
\hline \multirow[t]{4}{*}{ Responsiveness (RN) } & $\begin{array}{l}\text { RN1: Making information easily obtainable } \\
\text { by customers }\end{array}$ & $\begin{array}{l}\text { BSC will make information easily accessible } \\
\text { by clients and other stakeholders on the } \\
\text { building project }\end{array}$ & $\begin{array}{l}\text { BSC make information easily accessibility by } \\
\text { clients and other relevant stakeholders on } \\
\text { the building project }\end{array}$ \\
\hline & RN2: Giving prompt services to customers & $\begin{array}{l}\text { BSC will give prompt services to clients and } \\
\text { construction professionals on the project }\end{array}$ & $\begin{array}{l}\text { BSC give prompt services to clients and } \\
\text { construction professionals on the project }\end{array}$ \\
\hline & RN3: Willingness to always help customers & $\begin{array}{l}\text { BSC will always be willing to help clients } \\
\text { and other project team members on } \\
\text { the project }\end{array}$ & $\begin{array}{l}\text { BSC are always willing to help clients and } \\
\text { other project team members on } \\
\text { the project }\end{array}$ \\
\hline & $\begin{array}{l}\text { RN4: Never too busy to respond to } \\
\text { customers requests }\end{array}$ & $\begin{array}{l}\text { BSC will never be too busy to respond to } \\
\text { client's requests }\end{array}$ & $\begin{array}{l}\text { BSC are never too busy to respond to } \\
\text { client's requests }\end{array}$ \\
\hline \multirow[t]{4}{*}{$\begin{array}{l}\text { Assurance } \\
\text { (AS) }\end{array}$} & $\begin{array}{l}\text { AS1: Behaviour instilling confidence } \\
\text { in customers }\end{array}$ & $\begin{array}{l}\text { The behaviour of BSC will instil confidence } \\
\text { in clients }\end{array}$ & $\begin{array}{l}\text { The behaviour of BSC instil confidence in } \\
\text { their clients }\end{array}$ \\
\hline & $\begin{array}{l}\text { AS2: Customers feeling safe in their } \\
\text { transactions }\end{array}$ & $\begin{array}{l}\text { Clients will feel safe in their dealings with } \\
\text { BSC especially with security information } \\
\text { associated the building }\end{array}$ & $\begin{array}{l}\text { Clients feel safe in their transactions with } \\
\text { BSC especially with security information } \\
\text { associated with the building }\end{array}$ \\
\hline & AS3: Politeness to customers & $\begin{array}{l}\text { BSC will be able to provide adequate } \\
\text { technical personnel and other resources } \\
\text { for the tasks. }\end{array}$ & $\begin{array}{l}\text { BSC are able to adequately provide technical } \\
\text { personnel and other related resources for } \\
\text { the tasks }\end{array}$ \\
\hline & $\begin{array}{l}\text { AS4: Having knowledge to answer } \\
\text { customers' questions }\end{array}$ & $\begin{array}{l}\text { BSC will have knowledge to answer clients' } \\
\text { and other project team's issues and } \\
\text { concerns during the project delivery. }\end{array}$ & $\begin{array}{l}\text { BSC have knowledge to answer clients' and } \\
\text { other project team members' issues and } \\
\text { concern during the project delivery }\end{array}$ \\
\hline \multirow[t]{5}{*}{$\begin{array}{l}\text { Empathy } \\
\text { (EM) }\end{array}$} & EM1: Giving customer individual attention & $\begin{array}{l}\text { BSC will give project team members } \\
\text { individual attention and respond to } \\
\text { requests concerning the projects }\end{array}$ & $\begin{array}{l}\text { BSC give project team members individual } \\
\text { attention and respond to requests } \\
\text { concerning the projects }\end{array}$ \\
\hline & $\begin{array}{l}\text { EM2: Operating hours being convenient } \\
\text { to customers }\end{array}$ & $\begin{array}{l}\text { BSC will have operating hours for contact } \\
\text { convenient to clients }\end{array}$ & $\begin{array}{l}\text { Operating hours for contact of BSC are } \\
\text { convenient to clients }\end{array}$ \\
\hline & $\begin{array}{l}\text { EM3: Employees giving customers } \\
\text { personal service }\end{array}$ & $\begin{array}{l}\text { BSC will give clients specialized service } \\
\text { relating to MEP }\end{array}$ & $\begin{array}{l}\text { BSC give clients specialized service relating } \\
\text { to MEP }\end{array}$ \\
\hline & EM4: Having customers' interest at heart & $\begin{array}{l}\text { BSC will have their clients' interest over } \\
\text { other interests }\end{array}$ & $\begin{array}{l}\text { BSC have their clients' interest over } \\
\text { other interests }\end{array}$ \\
\hline & $\begin{array}{l}\text { EM5: Understanding the specific needs } \\
\text { of customers }\end{array}$ & $\begin{array}{l}\text { BSC will understand the specific needs of } \\
\text { the clients in relation to their objectives }\end{array}$ & $\begin{array}{l}\text { BSC understand the specific needs of the } \\
\text { clients in relation to their objectives }\end{array}$ \\
\hline
\end{tabular}

project team members $(\mathrm{RN} 1=6.08)$, BSC should have knowledge to answer clients' and other related project questions (AS4 $=6.23$ ), and BSC should understand the specific needs of their clients $(\mathrm{EM} 5=6.30)$. Other items even though have slightly lower score are considerably with high expectation from clients.

It is imperative to note that building services engineers should be up and doing as it concerns getting tasks done, providing on the spot assessment of client's concerns and issues and most importantly ensure relevant information are made available to stakeholders for decision making. One of the items with the lowest score is that the physical environment of building services engineers should be clean (TA4). This could be linked to the fact that the level of cleanliness of the physical environment of building services engineers is not directly associated with their service quality. The dimension with the highest expectation is reliability; closely following is assurance, responsiveness and empathy. While reliability is associated with the tendency to deliver on the promised service, assurance and responsiveness is known as the knowledge of employees in instilling trust and confidence and their tendency to readiness to help others and provide quick service respectively.

The items under client's perception on the service quality of building service engineers in building project delivery were slightly lower than their initial expectations prior to the start of 
Table 2. Descriptive results of the characteristics of the respondents of the study.

\begin{tabular}{lrc}
\hline & Frequency & Percent (\%) \\
\hline Professional background & & \\
Architect & 16 & 13.3 \\
Quantity Surveyor & 32 & 26.7 \\
Builder & 19 & 15.8 \\
Civil Engineer & 24 & 20.0 \\
Mechanical Engineer & 8 & 6.7 \\
Electrical Engineer & 16 & 13.3 \\
Others & 5 & 4.2 \\
Respondents' academic qualification & & \\
Higher National Diploma (Associate Degree) & 3 & 2.5 \\
B.Sc./B.Tech (Bachelors' Degree) & 51 & 42.5 \\
Postgraduate Diploma & 21 & 17.5 \\
M.Sc./M.BA (Masters' Degree) & 40 & 33.3 \\
PhD (Doctoral Degree) & 5 & 4.2 \\
Construction experience & & \\
1-10 years & 44 & 37.0 \\
11-20 years & 55 & 45.8 \\
21-30 years & 18 & 15.0 \\
Above 30 years & 3 & 2.2 \\
\hline
\end{tabular}

Table 3. Client's expectation of service quality of building service engineers.

\begin{tabular}{lllcc}
\hline S/N & Dimension & Code & $\begin{array}{c}\text { Expectation } \\
\text { Mean score }\end{array}$ & $\begin{array}{c}\text { Perception } \\
\text { Mean score }\end{array}$ \\
\hline 1. & Tangibles & TA1 & 5.97 & 5.56 \\
& & TA2 & 5.78 & 5.34 \\
& & TA3 & 5.60 & 5.50 \\
2. & Reliability & TA4 & 5.41 & 5.66 \\
& & RL1 & 6.22 & 5.91 \\
& RL2 & 6.22 & 6.02 \\
& & RL3 & 5.78 & 5.71 \\
& & RL4 & 6.10 & 5.78 \\
3. & RL5 & 6.17 & 5.78 \\
& Responsiveness & RN1 & 6.08 & 5.86 \\
& & RN2 & 6.02 & 6.04 \\
& & RN3 & 5.95 & 5.71 \\
4. & RN4 & 5.69 & 5.84 \\
& Assurance & AS1 & 6.10 & 5.73 \\
& & AS2 & 5.78 & 5.80 \\
& & AS3 & 5.78 & 5.86 \\
5. & AS4 & 6.23 & 6.02 \\
& & EM1 & 5.84 & 5.91 \\
& & EM2 & 5.69 & 5.80 \\
& & EM3 & 5.39 & 5.66 \\
& & EM4 & 6.04 & 5.88 \\
& & EM5 & 6.30 & 6.17 \\
\hline
\end{tabular}

the construction process. However, the following items have higher perception score and they include; Physical environment of building services engineers is clean (TA $4=5.66$ ), When clients have problems, building services engineers express sincere interest in solving the problem (RL2 $=6.02$ ), Building services engineers give prompt services to clients ( $\mathrm{RN} 2=6.04$ ), Building services engineers have knowledge to answer clients' questions (AS4 = 6.02), and building services engineers understand the specific needs of their clients $($ EM5 $=6.17)$. These scores are not too different with the scores of other items. It can thus be inferred that majority of the respondents reckon that the specific needs of the client in terms of briefs concerning building services were met. In the same vein, the knowledge of building services engineers is spot on concerning building services in project delivery as it is one of those areas client have little or no information about in the construction process but most importantly show sincere desire in helping the client regardless of his/her interest in the project.

It is however not surprising to note that tangible dimension (variables) had the least score when compared with reliability, responsiveness, assurance and empathy. This is evident with lowest perception score recorded against the cleanliness and neatness of the physical environment, availability of up-to-date equipment and the appealing nature of the physical facilities of the building services engineers. Clients are more concerned on the actual performance and the tendency to get value for money in the building project delivery.

\section{Service quality gap for building services engineering consultants}

This examines the service quality gap of building service engineers in building project delivery as perceived by client and client's professionals. The service quality is obtained such that expectation score is subtracted from perception score for each of the 5 service quality dimensions. Both expectation and perception score of the service quality of building service engineers in building project delivery was measured on the same 7-point Likert scale. As indicated in Table 3, it was revealed that client's expectation of service quality exceeded the actual perceived service obtained during the course of building project delivery. This gives rise to a negative gap score of the service quality. On the other hand, if the expectation score is lower than the perception score, there will be a positive gap score for service quality of building service engineers in building project delivery. Parasuraman et al. (1988) maintained that often, client's expectation usually exceeds the actual perceived service rendered and this confirms that there is usually reason for services to improve.

Table 3 depicts the perceived service quality gap of building services engineers and most significantly established the service quality dimensions that clients are impressed with the most. The gap scores are the differences in the perception scores and expectation scores of the service quality of building service engineers in building project delivery.

The difference signifies the level of the service quality and consequently the client's satisfaction of the services rendered. Table 4 indicated that expectation scores are more than perception scores except for 8 items in no particular order and they include; physical environment of building services engineers should be clean, building services engineers should never be too busy to respond to client's request, building services engineers should give prompt services to client, clients will feel safe in their transaction with building services engineers, building services engineers should be polite to clients, building services engineers should give customers individual attention and finally, building services engineers should have operating hours convenient for clients. The higher the perception scores, the better the perceived quality experienced by client in building project delivery. The largest positive gap score $(0.27)$ is found in the fact that building services engineers should give clients personal service required for their building product.

The other items had negative gap scores and hence revealed that expectations of service quality exceeded the perceived service quality during the construction process. The negative gap scores of those remaining items were between 0.07 and 0.44 . The high negative scores could be associated with the poor service quality of building services engineers or the over-expectation of the service quality by client or the hype by building services engineers themselves on the relevance of their service. Table 4 shows that service quality dimensions of tangible, responsiveness, reliability and assurance had negative gap scores while empathy had a positive gap score (perception higher than expectation). The positive gap score of empathy dimension could be as a result of the 
Table 4. Gap score of the service quality of building service engineering consultants.

\begin{tabular}{|c|c|c|c|c|c|c|c|}
\hline $\mathrm{S} / \mathrm{N}$ & Dimension & Code & $\begin{array}{c}\text { Perception } \\
\text { score }\end{array}$ & $\begin{array}{l}\text { Expectation } \\
\text { score }\end{array}$ & $\begin{array}{c}\text { Gap score } \\
(P-E)\end{array}$ & $\begin{array}{c}\text { Overall } \\
\text { gap score }\end{array}$ & $\begin{array}{c}\text { Average } \\
\text { gap score }\end{array}$ \\
\hline \multirow[t]{4}{*}{1.} & Tangibles & TA1 & 5.56 & 5.97 & -0.41 & -0.70 & -0.18 \\
\hline & & TA2 & 5.34 & 5.78 & -0.44 & & \\
\hline & & TA3 & 5.50 & 5.60 & -0.10 & & \\
\hline & & TA4 & 5.66 & 5.41 & 0.25 & & \\
\hline \multirow[t]{5}{*}{2.} & Reliability & RL1 & 5.91 & 6.22 & -0.31 & -1.20 & -0.24 \\
\hline & & RL2 & 6.02 & 6.22 & -0.20 & & \\
\hline & & RL3 & 5.71 & 5.78 & -0.07 & & \\
\hline & & RL4 & 5.78 & 6.10 & -0.22 & & \\
\hline & & RL5 & 5.78 & 6.17 & -0.39 & & \\
\hline \multirow[t]{4}{*}{3.} & Responsiveness & RN1 & 5.86 & 6.08 & -0.22 & -0.29 & -0.07 \\
\hline & & RN2 & 6.04 & 6.02 & 0.02 & & \\
\hline & & RN3 & 5.71 & 5.95 & -0.24 & & \\
\hline & & RN4 & 5.84 & 5.69 & 0.15 & & \\
\hline \multirow[t]{4}{*}{4.} & Assurance & AS1 & 5.73 & 6.10 & -0.37 & -0.48 & -0.12 \\
\hline & & AS2 & 5.80 & 5.78 & 0.02 & & \\
\hline & & AS3 & 5.86 & 5.78 & 0.08 & & \\
\hline & & AS4 & 6.02 & 6.23 & -0.21 & & \\
\hline \multirow[t]{6}{*}{5.} & Empathy & EM1 & 5.91 & 5.84 & 0.07 & 0.16 & 0.03 \\
\hline & & EM2 & 5.80 & 5.69 & 0.11 & & \\
\hline & & EM3 & 5.66 & 5.39 & 0.27 & & \\
\hline & & EM4 & 5.88 & 6.04 & -0.16 & & \\
\hline & & EM5 & 6.17 & 6.30 & -0.13 & & \\
\hline & Overall perceived service quality & & & & & & -0.58 \\
\hline
\end{tabular}

Table 5. Average score and ranking of service dimension of building service engineers.

\begin{tabular}{lcc}
\hline Dimension & Average gap score & Ranking \\
\hline Empathy & 0.03 & $1 \mathrm{st}$ \\
Responsiveness & -0.07 & $2 \mathrm{nd}$ \\
Assurance & -0.12 & $3 \mathrm{rd}$ \\
Tangible & -0.18 & $4 \mathrm{th}$ \\
Reliability & -0.24 & 5 th \\
\hline
\end{tabular}

variables associated with the understanding of the client and not linked with the main duties of building services engineers as required in the building project delivery process.

It was obtained from Table 4 that the perceived quality did not meet up with the expectation of the services of building service engineers especially in four out of the five service quality dimensions.

\section{Tangible}

Clients of building projects are not impressed with the cleanliness, neatness and nature of the physical environment and the facilities of building service engineers. In the same light, the software used are not up to date; hence the gap score $(-0.70)$ with an average gap score of $(-0.18)$. Invariably, clients tend to expect more in terms of the physical environment and the use of up-todate equipment which will make the work and services of building services engineers efficient amongst others. This dimension is rated fourth amongst the five service dimension considered for the study. Jassawalla and Sashittal (1999) submitted that higher productivity of employees is the result of work environment that boosts inventiveness and innovation. Cleland (1999) corroborated that conducive work environment is considered significant in enhancing consultants' or project managers' efficiency as well as and the use of up-to-date software.

\section{Responsiveness}

Responsiveness dimension overall gap score was pegged at -0.29 , while the average gap score of the dimension as revealed by Table 5 is 0.07 . It is ranked second among the other dimension as clients are rarely satisfied with ease of information availability, prompt nature of the services, willingness to help and the level of busyness associated with responding to client's and other relevant stakeholder's request. This reaffirms the position of Wasi et al. (1970) that communication between workers on site and the office of contractor is limited in developing countries. Resultantly, urgent site problems cannot be solved immediately (Abdullah et al. 2012). This indirectly will reflect in the negative performance of building projects.

\section{Reliability}

This is the dimension that clients are disappointed and dissatisfied with the most among the service dimension. This was confirmed with its average gap score of -0.24 and overall gap score of -1.20 revealed in Tables 4 and 5 respectively. Clients are not satisfied greatly about the timing of responses of tasks, their sincere interest in solving problems, ability to keep records accurately and tendency to get the tasks right at first time of asking. This is confirmed with its last position ranking among the service dimension as depicted in Table 4. If consultants are not firm on making and agreeing on decisions affecting the prompt delivery of projects, such laxity always result in delays and cost overruns. Iyer and Jha (2005) discovered that timely decision making enhances response rate and can improve schedule of time and cost performance.

\section{Assurance}

This service dimension is rated third in Table 5 with an overall gap score of -0.48 and an average gap score of -0.12 . The clients are seldom satisfied with the ability of building services engineers to instil confidence, the tendency for client to feel safe with building services engineers, politeness of building services engineers to the clients and their knowledge to address client's questions in the building process. The findings indicated that there is relative poor quality service delivery. Knowledge, courtesy and ability to inspire trust and confidence in clients are 
important consideration for clients' satisfaction. Levesque and McDougall (1996) affirmed that satisfaction emanate from the overall attitude of consultants to clients. Also, organizations or firms that consistently satisfy their customers enjoy higher level of retention and greater profitability all because of increased customers' loyalty (Wicks and Roethlein 2009).

\section{Empathy}

Empathy dimension had a positive overall gap score of 0.16 while the average gap score of the dimension is 0.03 . The perceived quality of client is higher than the expectations of the client during the building project delivery. The clients are hitherto satisfied with the attention accorded to the clients, convenient operating hours, the personal service rendered during the process, the interest of the client at heart and finally, the ability to meet the specific needs of the clients. Exhibiting individualized attention to clients will do lots of good to building services engineers. Wicks and Roethlein (2009) affirmed that organizations that consistently satisfy their customers enjoy higher level of retention and greater profitability, all owing to increased customers' loyalty.

As indicated in Table 5, it is obvious that client regard the actual service quality of building services engineers to be poor in all dimensions except empathy; thus showing that their expectations are not met when compared with their subsequent experiences in building project delivery as it concerns the building services. Therefore, it is safe to say that clients were only satisfied with the empathy dimension while they were dissatisfied with the others. The other dimensions have a gap between expected service quality and perceived or actual service process during the process, hence there is need for improvement in the service quality of building services engineers in building delivery process and ultimately will lead to increased client's satisfaction and the achievement of project objectives.

\section{Conclusion and implications}

Service quality relates to the overall examination of a service by clients or customers. Service quality assessment or measurement is important in that it charts the course for bridging the gap, difference or discrepancy between customers' expectations for an offered service and customers' perceptions of the service received. The consultant services engineers are one of clients' representatives in the delivery construction projects. As the ground to ensuring good service quality is to either meet or exceed customers' expectation from the service, it is important that building services engineers identify areas where they lag in service provision in order to improve on them and continually raise the standard of service quality dimension(s) which passes clients' perception.

The study concludes that construction clients are not impressed with the physical nature of the environment of services consultant as well as the level of information available during the construction process. Similarly, clients are far from impressed with the promptness in responding to stakeholders' requests and queries. In the same vein, record keeping by consultants and ability to produce deliverables at the first time of asking is another source of concern expressed by the clients during construction project delivery. However, it was established that clients are more than satisfied with the interest of the client and its ability to meet the specific needs of the clients.
The paper presents contribution to literature regarding the clients' perspective of service quality of building services engineering consultants in building project delivery. While majority of literature focussed on clients' satisfaction of construction consultants, this study provided the service quality gap in the performance of specialized construction consultants in building project delivery.

The study recommends that building services engineering consultants should be conscientious by timeously responding to all instructions and requests of clients. Furthermore, building services engineers should identify and consider potential areas of problems as identified in the study and then design mitigation measures of framework to prevent the problems and at the same time improve the consultants' reputation which will ultimately positively rob off in project outcome. The continuous examination of customers' perceptions and expectations is needed to know what actually the customers want. In this regard, building services consultants should imbibe the culture of measuring clients' stated needs and demands which in turn will lead to improved service quality.

The limitation of the study is hinged on the fact that the research examined the service quality of an important building consultant in the delivery process within the Lagos metropolis with very few target respondents. Another research can be carried out with a larger sample from the six geographical zones of the country. In the same light, the study assessed the input of services engineers for building projects from client's perspectives generally i.e. it is limited to the assessment of the general perception of clients. Another research could be carried out to examine the comparative assessment of service quality of building services engineers in private and public sectors construction projects. Furthermore, the results of the study indicated that there is gap regarding ease of information availability, prompt service delivery, disposition to help clients as well as the level of busyness associated with responding to client's request. The causes of these under performance should be investigated in order not to jeopardize satisfaction of clients.

\section{Disclosure statement}

No potential conflict of interest was reported by the author(s).

\section{References}

Abdullah A, Bilau A, Enegbuma W. 2012. Small and medium sized construction firms job satisfaction and performance evaluation in Nigeria. Int J Soc Sci Humanity. 2(1):35-40.

Aga M, Safakli OV. 2007. An empirical investigation of service quality and customer satisfaction in professional accounting firms: evidence from North Cyprus. Probl Perspect Manage. 5(3):84-98.

Chen PD, Mathies C. 2016. Assessment, evaluation, and research. New Direct High Educ. 2016(175):85-92.

Chow LK, Ng ST. 2003. Performance-based evaluation for engineering consultants: a study of assessment criteria. In: Greenwood DJ, editor. 19th Annual ARCOM Conference; Sep 3-5 September 2003; University of Brighton. Association of Researchers in Construction Management; vol. 1, p. 433-442.

Christodoulou S, Griffis H, Barrett L, Okungbowa M. 2004. Qualifications based selection of professional A/E services. J Manage Eng. 20(2):34-41.

Cleland D. 1999. Project management: strategic design and implementation. Singapore: McGraw-Hill Book Company.

Cox A, Thompson I. 1997. Fit for purpose contractual relations: determining a theoretical framework for construction projects. Eur J Purch Supply Manage. 3(3):127-135.

Dadzie J, Abdul-Aziz AR, Kwame A. 2012. Performance of consultants on government projects in Ghana. Int J Bus Soc Res. 2(6):256-267. 
Dosumu OS, Aigbavboa C. 2019. Assessing clients' satisfaction with the service quality of construction consultants in Lagos, Nigeria. Afr J Sci Technol Innov Dev. 11(6):771-779.

Eshghi A, Roy S, Ganguli S. 2008. Service quality and customer satisfaction: an empirical investigation in Indian mobile telecommunications services. Mark Manage J. 18:119-144.

Forsythe P. 2015. Monitoring customer perceived service quality and satisfaction during the construction process. Constr Econ Build. 15(1):19-42.

Ghylin KM, Green BD, Drury CG, Chen J, Schultz JL, Uggirala A, Abraham JK, Lawson TA. 2008. Clarifying the dimensions of four concepts of quality. Theor Issues Ergon Sci. 9(1):73-94.

Govender R, Saba G, Ham N, Hou L, Moon S, Kim J. 2019. Appraisal of building information modelling (BIM) curriculum for early-career construction industry professionals: case study at $C$ educational institute in Korea. Int J Constr Manage. 19:1-9.

Gyadu-Asiedu W. 2009. Assessing construction project performance in Ghana: modelling practitioners' and clients' perspectives. Eindhoven: Technische Universiteit Eindhoven.

Hattan D, Lalani N. 1997. Selecting the right consultant team. Inst Transport Eng J. 67(9):40-46.

Hoxley M. 2000. Are competitive fee tendering and construction professional service quality mutually exclusive? Constr Manage Econ. 18(5):599-605.

Idoro G. 2009. Evaluating levels of project planning and their effects on performance in the Nigerian construction industry. Const Econ Build. 9(2): 39-50.

Ingle PV, Mahesh G. 2020. Construction project performance areas for Indian construction projects. Int J Constr Manage. DOI: 10.1080/ 15623599.2020.1721177.

Iyer KC, Jha KN. 2005. Factors affecting cost performance: evidence from Indian construction projects. Int J Project Manage. 23(4):283-295.

Jassawalla A, Sashittal H. 1999. Building collaborative cross-functional new product teams. Acad Manage Exec. 13(3):50-63.

Kemper TD, editor. 1990. Research agendas in the sociology of emotions. Albany (NY): State University NY Press.

Levesque T, McDougall GHG. 1996. Determinants of customer satisfaction in retail banking. Int J Bank Mark. 14(7):12-20.

Lichtig W. 2006. The integrated agreement for lean project delivery. Constr Lawyer. 26(3):1-8.

Love PED, Smith J, Treloar GJ, Li H. 2000. Some empirical observations of service quality in construction. Eng Constr Arch Manage. 7(2):191-201.

$\mathrm{Ng}$ ST. 2005. Performance of engineering consultants in ISO 9000-based quality management systems implementation. Eng Const Arch Mgt. 12(6): 519-532.

Nojavan M, Heidari A, Mohammaditabar D. 2020. A fuzzy service quality based approach for performance evaluation of educational units. SocioEcon Plan Sci. 100816. DOI: 10.1016/j.seps.2020.100816.

Nunkoo R, Teeroovengadum V, Ringle CM, Sunnassee V. 2019. Service quality and customer satisfaction: the moderating effects of hotel star rating. Int J Hosp Manage. 102414. DOI: 10.1016/j.ijhm.2019.102414.
Ojelabi R, Oyeyipo O, Afolabi A, Amusan L. 2018. Presence of social client relationship management within the Nigerian Construction Industry. Buildings. 8(4):60-75.

Olanrewaju A. 2016. Measuring the service gaps in the roles of quantity surveyors in the emerging market. Benchmarking. 23(5):1111-1131.

Oluwatayo AA, Ibem E, Amole D. 2014. Satisfaction of first-time residential clients with architectural services. J Eng Des Technol. 12(3):316-335.

Othman AAE. 2015. An international index for customer satisfaction in the construction industry. Int J Constr Manage. 15(1):33-58.

Oyeyipo O, Odeyinka H, Owolabi J, Ojelabi R. 2019. Factors promoting stakeholder management of building projects. Int J Mech Eng Technol. 10(4):42-49.

Pallant J. 2010. SPSS survival manual: a step by step guide to data analysis using SPSS. 4th ed. Maidenhead (NY): Open University Press/McGraw Hill.

Parasuraman A, Zeithaml VA, Berry LL. 1988. SERVQUAL: a multiple-item scale for measuring consumer perception. J Retail. 64(1):12-40.

Rosli NS, Hamsa A. 2005. Measurement of performance-service indicators of KLIA transit. A paper presented at the 13th World Conference on Transportation Research held on 15-18th July 2013 at Rio de Janeiro, Brazil.

Roy S, Sreejesh S, Bhatia S. 2019. Service quality versus service experience: an empirical examination of the consequential effects in B2B services. Ind Mark Manage. 82(2019):52-69.

Sallehan IH, Mohamad O, Sufian CA. 2012. Measuring refurbishment con tractors' service quality and client satisfaction: a case study at public institutions of higher education. Pertanika J Sociol Humanit. 20(1):107-120.

Tahanisaz S, Shokuhyar S. 2020. Evaluation of passenger satisfaction with service quality: a consecutive method applied to the airline industry. J Air Transp Manage. 83(2020):101764-101710.

Tan ESE. 2012. A study of architects' perceptions of consulting engineers service quality [dissertation]. Western Australia: University of Western Australia.

Tayeh BA, Al-Hallaq K, Alaloul WS, Kuhail AR. 2018. Factors affecting the success of construction projects in Gaza Strip. Open Civ Eng J. 12(1): $301-315$.

Ullman D. 2001. Robust decision-making for engineering design. J Eng Des. 12(1):3-13.

Usman N, Said I, Yahaya AZ. 2012. Indolent disposition towards ICT acceptance among practising quantity surveyors in Nigeria. Acta Tech Corviniencis Bull Eng. 5(2):75.

Viadiu FM, Fa MC, Saizarbitoria IH. 2002. Do quality consultants offer a quality service? Total Qual Manage. 13(6):797-811.

Wasi D, Bridge A, Skitmore RM. 1970. Factors affecting the performance of small indigenous contractors in Papua New Guinea. Constr Econ Build. 1(1):80-90.

Wicks AM, Roethlein CJ. 2009. A satisfaction-based definition of quality. J Bus Econ Stud. 15(1):82-97. 